\title{
Brick Cost Analysis Based on Dimensions
}

\author{
Putri Lynna A. Luthan ${ }^{1 *}$, Nathanael Sitanggang ${ }^{1}$, Harun Sitompul ${ }^{1}$ \\ \{*putri.lynna@unimed.ac.id\} \\ ${ }^{1}$ Faculty of Engineering, Universitas Negeri Medan, Indonesia
}

\begin{abstract}
This study aims to compare the unit price of the cost of a brickworks between the bricks with size based on market and based on with Indonesian National Standard (SNI) 2008 for brick wall instalation. The sample was determined by a random sampling technique with 100 bricks that traded in Medan City. The data collection tool used is open questionnaire. Data analysis done by using descriptive statistical analysis and unit price analysis based on SNI 6897: 2008. The results found that there is a difference in the unit price of the brickworks between bricks with SNI size and brick with market size, that is $11.45 \%$. The installation of a wall with brick size according to SNI is more cost effective compared to the of bricks with market size. This finding can be used by planner and contractor consultants as a basis for making decisions to make offers in accordance with the availability of brick materials traded in the area around the project.
\end{abstract}

Keywords: costs, bricks, dimensions

\section{Introduction}

The rapid development of housing is currently opening up opportunities for building materials companies to provide building materials. Bricks are one of the most widely used building materials for building walls and parapets. To determine the cost of building construction, the government made the Indonesian National Standard (SNI) 2008 as a benchmark for consultants and contractors to calculate the unit price of the budget for the cost of building materials and labor needed. The use of the analysis list is adjusted to the type of construction and materials used. The unit cost price of a standard size brickworks is planned using the unit price of the 2008 SNI budget as shown in Table 1.

Table 1. Brickworks unit price budgeting based on SNI

\begin{tabular}{|c|c|c|c|c|}
\hline \multicolumn{5}{|c|}{ Material } \\
\hline 70.00 & Pc & $\begin{array}{l}\text { Machine } \\
\text { Casted Bricks }\end{array}$ & (a) Rp. & $=\mathrm{Rp}$. \\
\hline 11.50 & $\mathrm{Kg}$ & $\begin{array}{l}\text { Portland } \\
\text { Cement }\end{array}$ & (a) Rp & $=\mathrm{Rp}$. \\
\hline \multirow[t]{2}{*}{0.043} & $\mathrm{M}^{3}$ & Sand & (a) Rp. & $=\mathrm{Rp}$. \\
\hline & & & Total 1 & $=\mathrm{Rp}$. \\
\hline \multicolumn{5}{|c|}{ Labour } \\
\hline 0.30 & Md & Laborer & (a) Rp. & $=\mathrm{Rp}$. \\
\hline 0.10 & $\mathrm{Md}$ & Bricklayer & (a) Rp. & $=\mathrm{Rp}$. \\
\hline 0.01 & $\mathrm{Md}$ & Head Laborer & (a) Rp. & $=\mathrm{Rp}$. \\
\hline \multirow[t]{2}{*}{0.015} & Md & Foreman & (a) Rp. & $=\mathrm{Rp}$. \\
\hline & & & Total 2 & $=\mathrm{Rp}$. \\
\hline
\end{tabular}




\begin{tabular}{ll}
\hline A. Sum Total 1+2 & $=\mathrm{Rp}$. \\
\hline B. Overhead and Profit $15 \% \times \mathrm{A}=\mathrm{Rp}$. \\
\hline C. Unit Price of Work $(\mathrm{A}+\mathrm{B})$ & $=\mathrm{Rp}$. \\
\hline
\end{tabular}

Table 1 shows that for $1 \mathrm{~m}^{2}$ brickwork, 70 pieces of SNI standard bricks are needed. The size of the standard SNI bricks issued by the Department of Public Works and Public Housing in 2013 is: length $=22 \mathrm{~cm}$, width $=11 \mathrm{~cm}$, and height $=5 \mathrm{~cm}$. However, based on observations, the size of bricks traded in the city of Medan has decreased from the standard size. From each of the 3 brick sellers at locations A and B, the dimensions of the brick can be seen in Table 2.

Table 2. Dimensions of traded bricks $(\mathrm{Cm})$

\begin{tabular}{cccc} 
Location & Length & Width & Height \\
& 18.8 & 10 & 4.3 \\
Location A & 18.3 & 9.5 & 4.4 \\
& 19 & 10 & 4.5 \\
& 18.5 & 9 & 4.5 \\
Location B & 19 & 9.5 & 4.5 \\
& 19 & 9.5 & 4.5 \\
\hline
\end{tabular}

Table 2 shows that the dimensions of bricks traded have been reduced from the dimensions that based on SNI. Decreasing the dimensions of the brick will increase the number of bricks and other materials, so that the unit price of the budget increases, which will harm consumers. Therefore, the problem that being examined is: How is the effect of the unstandardized bricks to the unit price of brickworks using SNI 2008?

\section{Methodology}

\subsection{Bricks Material Origin}

Bricks are building elements made from clay and casted in the form of beams and after being burned it will become hard. Bricks are used for building walls and for foundation construction alternative material. Clay that can be used is clay containing porcelain soil mixed with quartz sand powder, iron oxide $\left(\mathrm{Fe}_{2} \mathrm{O}_{3}\right)$ powder, and lime powder $\left(\mathrm{CaCo}_{3}\right)$. Clay is taken from the soil surface. The color of the clay varies depending on the metal, aluminum, iron, and calcium oxidants they contain. Usually clay is dark brown, gray and dark blue. The use of bricks, among others, is as a wall that can protect the contents of the building [1].

\subsection{Brick requirements that can be used for buildings}

The bricks that will be used for buildings must meet the following conditions, namely: 1) Outside views: red brick must have sharp and angled ribs, flat sides, not cracked, and no changes in shape excessive; 2) Dimensions: according to SNI, bricks are length $=22 \mathrm{~cm}$, width $=11 \mathrm{~cm}$, and height $=5 \mathrm{~cm}$; and 3) Compressive strength: the compressive strength of the level I brick quality is greater than $100 \mathrm{~kg} / \mathrm{cm}^{2}$, the level II brick is $100-80 \mathrm{~kg} / \mathrm{cm}^{2}$, and the quality of the level III brick is $80-60 \mathrm{~kg} / \mathrm{cm}^{2}$. Brick is a basic material used as building materials that are most widely used for walls of buildings and parapets, generally brick making is done conventionally. Conventional brick making produces different sizes depending on the manufacturer [2], so that the bricks in the market have various sizes that will affect the 
number of bricks used for each $\mathrm{m}^{2}$ and the size of the spaces thickness. The size of standard bricks according to SK SNI 04-1989-F is as shown in Table 3.

Table 3. Bricks Size according to SK SNI 04-1989-F

\begin{tabular}{llll}
\hline \multirow{2}{*}{ Module } & \multicolumn{3}{c}{ Size $(\mathrm{mm})$} \\
\cline { 2 - 4 } & Length & Width & Height \\
\hline M-5a & 190 & 90 & 65 \\
$M-5 b$ & 190 & 140 & 65 \\
M-6 & 220 & 110 & 50 \\
\hline
\end{tabular}

According to NI 10, the biggest deviation, from the size of the bricks found in Table 3, for a maximum length of $3 \%$, maximum width of $4 \%$ and maximum thickness of $5 \%$.

\subsection{Cost Budget}

In constructionwork, the costs that will be incurred for a construction project must be calculated in detail, because the cost is a large investment that must be provided by the contractor in the construction phase. Accuracy in calculating volume and accuracy in determining costs is very important in planning. According to [2], the lack of thoroughness of an estimator in calculating the required budget will cause cost overruns to complete a job. The cost element required in a construction consists of labor, material, equipment, market and capital. With the control of the material used, the value of profits in a construction project will be optimally achieved by doing the work effectively and efficiently.

For data collection, survey method is used. The used tool for data collection is open questionnaire [3] consisting of several columns of length, width, and height of the bricks. The size of the brick that used as a comparison is $22 \mathrm{~cm}$ long, $11 \mathrm{~cm}$ wide and $50 \mathrm{~cm}$ high [4]. The study was conducted at the location of brick sales that are domiciled in Medan City. Samples totaling of 100 pieces were determined by random sampling technique [5]. For data analysis, descriptive statistical analysis techniques is used [6].

\section{Result and Discussion}

Based on the results of descriptive analysis of survey data, the dimensions of the bricks traded obtained an average length of $18.77 \mathrm{~cm}$, width $9.58 \mathrm{~cm}$, and height of $4.45 \mathrm{~cm}$. These results show the dimensions of the bricks traded are smaller than the dimensions of the bricks based on SNI 6897: 2008 with the length of $22 \mathrm{~cm}$, width of $11 \mathrm{~cm}$, and thickness of $5 \mathrm{~cm}$. Based on the analysis of SNI 6897: 2008 unit price, for the installation of $1 \mathrm{~m}^{2}$ brick wall, 70 pieces are needed, with $1.5 \mathrm{~cm}$ spacing as an adhesive between bricks, then the number of bricks needed for the wall $1 \mathrm{~m}^{2}$ becomes $10,000 /(22+1.5) \times(5+1.5)=66$ pieces plus a safety factor of $6 \%$ then become 70 pieces. Whereas based on the dimensions of the traded bricks, the number of bricks needed for the wall of $1 \mathrm{~m}^{2}$ with $1.5 \mathrm{~cm}$ speacing is $10,000 /$ $(18.77+1.5) \times(4.45+1.5)=83$ pieces plus a safety factor of $6 \%$ then become 88 and Then the unit price of bricks instalation cost based on SNI 6897: 2008 can be seen in Table 4.

Tabel 4. Analysis of brickwork based on the dimensions of SNI 6897: 2008

\begin{tabular}{|c|c|c|c|c|}
\hline \multicolumn{5}{|c|}{ Material } \\
\hline 70.00 & Pc & $\begin{array}{l}\text { Machine Casted } \\
\text { Bricks }\end{array}$ & (a) Rp. 550 & $=$ Rp. 38,500, \\
\hline
\end{tabular}




\begin{tabular}{|c|c|c|c|c|}
\hline 11.50 & $\mathrm{Kg}$ & Portland Cement & (a) Rp. 1,500 & $=$ Rp. $17,250,-$ \\
\hline \multirow[t]{2}{*}{0.043} & $\mathrm{M}^{3}$ & Sand & (a) Rp. 150,000 & $=$ Rp. $5,375,-$ \\
\hline & & & Total 1 & $=$ Rp. 61,125,- \\
\hline \multicolumn{5}{|c|}{ Labour } \\
\hline 0.30 & $\mathrm{Md}$ & Laborer & (a) Rp. 80,000 & $=$ Rp. $24,000,-$ \\
\hline 0.10 & $\mathrm{Md}$ & Bricklayer & (a) Rp. 100,000 & $=$ Rp. 10,000,- \\
\hline$\overline{0.01}$ & $\mathrm{Md}$ & Head Laborer & (a) Rp. 120,000 & $=$ Rp. $1,200,-$ \\
\hline \multirow[t]{6}{*}{0.015} & $\mathrm{Md}$ & Foreman & (a) Rp. 150,000 & $=$ Rp. $2,250,-$ \\
\hline & & & Total 2 & $=$ Rp. 37,450,- \\
\hline & & A. Sum Total $1+2$ & & $=$ Rp. $98,575,-$ \\
\hline & & B. Overhead and & it $15 \% \times \mathrm{A}$ & $=$ Rp. $14,786.25,-$ \\
\hline & & C. Unit Price of $\mathrm{V}$ & $(A+B)$ & $=$ Rp. $113,361.25,-$ \\
\hline & & Rounded & & $=$ Rp. $113,500.00,-$ \\
\hline
\end{tabular}

Table 4 shows the unit price of brickwork cost based on SNI 6897: 2008 is Rp. 113,500,while the unit price of brickwork cost based on the survey results is Rp. 126,500, - For details, see Table 5 .

Table 5. Analysis of brickwork cost based on market dimension

\begin{tabular}{|c|c|c|c|c|}
\hline \multicolumn{5}{|c|}{ Material } \\
\hline 88.00 & $\mathrm{Pc}$ & $\begin{array}{l}\text { Machine Casted } \\
\text { Bricks }\end{array}$ & (a) Rp.550 & $=$ Rp. $44,000,-$ \\
\hline$\overline{14.46}$ & $\mathrm{Kg}$ & Portland Cement & (a) Rp. 1,500 & $=$ Rp. 21,690.- \\
\hline \multirow[t]{2}{*}{$\overline{0,054}$} & $\mathrm{M}^{3}$ & Sand & (a) Rp. 150,000 & $=$ Rp. 6,750,- \\
\hline & & & Total 1 & $=$ Rp. 72,440,- \\
\hline \multicolumn{5}{|c|}{ Labour } \\
\hline 0.30 & $\mathrm{Md}$ & Laborer & (a) Rp. 80,000 & $=$ Rp. $24,000,-$ \\
\hline$\overline{0.10}$ & $\mathrm{Md}$ & Bricklayer & (a) Rp. 100,000 & $=$ Rp. 10,000,- \\
\hline$\overline{0.01}$ & $\mathrm{Md}$ & Head Laborer & (a) Rp. 120,000 & $=$ Rp. $1,200,-$ \\
\hline \multirow[t]{6}{*}{$\overline{0.015}$} & $\mathrm{Md}$ & Foreman & (a) Rp. 150,000 & $=$ Rp. $2,250,-$ \\
\hline & & & Total 2 & $=$ Rp. 37,450,- \\
\hline & & A. Sum Total $1+2$ & & $=$ Rp. $109,890,-$ \\
\hline & & B. Overhead and I & rofit $15 \% \times \mathrm{A}$ & $=$ Rp. 16,483.50,- \\
\hline & & C. Unit Price of $\mathrm{W}$ & ork $(\mathrm{A}+\mathrm{B})$ & $=$ Rp. 126,373.50,- \\
\hline & & Rounded & & $=$ Rp. $126,500,-$ \\
\hline
\end{tabular}

The difference in unit price of the brickworks between SNI 6897: 2008 and market bricks is $11.45 \%$. This finding shows that the cost unit price analysis of SNI-sized brickworks is more economical compared to the cost of brickworks with the market size. This finding supports the findings of Mufaris, Prihesnanto, and Darma who found that cost budget estimates calculated based on SNI were more economical than budget estimates based on Burgelijke Openbare Werken (BOW) analysis [7]. The author agrees with Fatonah and Wulansari [8] who suggest choosing the right and accurate calculation method to obtain more efficient budgetary results. This finding provides very valuable guidance to the planner and contractor consultants as consideration for submitting an offer that is in accordance with the brick material traded in the area around the project. 


\section{Conclusion}

Based on the results and discussion, it is concluded that the dimensions of bricks that are not in accordance with the dimensions of SNI cause a difference in the unit price of the budget for the installation of the wall as big as $11.45 \%$. The unit price of the budget for the installation of standard size brick walls is more efficient than using bricks that are traded on the market.

\section{References}

[1] C. Fianli, Dinding Bangunan. Universitas Diponegoro. Bandung. Semarang: Universitas Diponegoro, 2011.

[2] G. Susanta, Dinding. Jakarta: Penebar Swadaya, 2007.

[3] Riduwan, Skala Pengukuran Variabel-variabel Penelitian. Bandung: Alfabeta, 2009.

[4] S. Handayani, "Kualitas Batu Bata Merah dengan Penambahan Serbuk Gergaji," J. Tek. Sipil dan Perenc., vol. 12, no. 1, pp. 41-50, 2010.

[5] W. G. Cochran, Sampling Techniques. Terjemahan Rudiansyah. Jakarta: UI-Press., 2005.

[6] Sugiyono, Metode Penelitian Kuantitatif Kualitatif dan R \& D. Bandung: Alfabeta, 2008.

[7] Mufaris, A. M., Prihesnanto, Fajar, Darma, and Eko, “. Perbandingan estimasi anggaran biaya antara BOW, SNI dan Metode Perhitungan Kontraktor pada proyek rumah susun (Rusun) Pulogebang Jakarta Timur," 2018.

[8] Fatona, Dwi Novi, Kurnia, and Wulansari, "Estimasi Anggaran Biaya Struktur Proyek Pembangunan Hotel Quad Makassar Menggunakan Metode SNI,” J. Kaji. Tek. Sipil, vol. 2, no. 2, pp. 36-44, 2018. 